\title{
FAKTOR YANG BERHUBUNGAN DENGAN KEPEMILIKAN JAMBAN SEHAT DI DESA NAMBANGAN KIDUL MANGUHARJO KOTA MADIUN
}

\author{
Eny Pemilu Kusparlina \\ Fakultas Ilmu Formal dan Ilmu Terapan, Universitas Muhammadiyah Madiun \\ Email : pemilu77@yahoo.co.id
}

\begin{abstract}
The World Bank states that the 2018 data $22 \%$ of Indonesian people has not had a sanitation facility (latrine). The existence of latrines in Indonesia, according to World Bank data in 2015 about 22\% of Indonesia's population does not have latrines. The coverage of national guard to urban areas with $79 \%$ and $49 \%$ for rural areas. Most of the sludge removal used the river or dug wells which do not have the requirements of health latrine and contiminate the ground water. Based on the data obtained from the Health Center Community Manguharjo in 2019 of 855 homes were inspected as many as 530 households, households have basic sanitation facilities such as latrines in the Health Center Community Manguharjo downstream for 420 households or 79\%. This study aims to determine the relationship between the factors of income, knowledge, and attitude, with the ownership of latrines in Madiun City, Manguharjo. The research method used observational design with cross sectional approach. The sample are mothers who have children under five do not have latrines that 64 respondents. The sampling technique used random sampling. Statistical analysis used chi square test. Decision of research hypothesis testing based on the significance level of 5\% $(p=0.05)$ and confidence interval (CI) 95\%. The result showed that there are relationship between income and the latrine ownership $(p=0.037)$, knowledge $(p=0.037)$ and attitude $(p=0.037)$. The result showed no relationship between education $(p=0196)$, and the role of health care workers $(p=1.000)$ with the ownership of latrines in the Madiun City, Manguharjo.
\end{abstract}

Keywords: Latrine, income, knowledge, attitude

\section{PENDAHULUAN}

Penyediaan air bersih,pembuangan kotoran, pembuangan air limbah, dan pembuangan sampah merupakan syarat rumah sehat. Pembuangan kotoran/tinja, yang biasa juga disebut dengan tempat Buang Air Besar (BAB) merupakan bagian yang penting dalam sanitasi lingkungan. Pembuangan tinja manusia yang tidak memenuhi syarat sanitasi dapat menyebabkan terjadinya pencemaran tanah serta penyediaan air bersih, dan memicu hewan vektor penyakit, misalnya lalat, tikus atau serangga lain untuk bersarang, berkembang biak serta menyebarkan penyakit. Hal tersebut juga tidak jarang dapat menyebabkan timbulnya bau yang tidak sedap (Putranti, 2013).

Wabah penyakit pada masyarakat akan meluas jika masih terjadi Buang Air Besar Sembarangan (BABS), misalnya BAB di kebun, sungai dan tempat lain yang kurang memenuhi syarat jamban sehat (Erlina, 2015).

Diare menempati urutan nomor satu, sebesar $72 \%$, prevalensi penyakit akibat sanitasi buruk (WSP-EAP. 2008). Faktor agent, penjamu (host), lingkungan, pelayanan kesehatan, dan perilaku merupakan faktorfaktor yang berkaitan dengan kejadian diare pada balita. Tidak diberikannya ASI (Air Susu Ibu) eksklusif, kurang gizi, munculnya penyakit infeksius, keturunan, dan imunodefisiensi, menjadi faktor penjamu yang berakibat terjadinya kerentanan diare. Pembuangan tinja adalah satu diantara faktor lingkungan yang paling sering menyebabkan diare, yang kemudian dilanjutkan dengan kurangnya sarana air bersih, adanya vektor dan penanganan sampah (Yulianto, 2016).

$\mathrm{Hal}$ tersebut mendukung dari hasil penelitian Darsana, yang menunjukkan bahwa selain faktor pendidikan dan pengetahuan mengenai sarana sanitasi, terdapat adanya hubungan yang bermakna antara kepemilikan jamban dengan kejadian diare, ditambah dengan faktor kondisi lingkungan serta perilaku (kebiasaan) masyarakat membuang kotoran. Begitu pula dengan peran petugas kesehatan sebagai penunjang pencegah kejadian Diare (Darsana, 2014).

Mengutip dari CNN Indonesia tentang laporan Join Monitoring Program (JMP) WHO/Unicef, ternyata masih terdapat $12,9 \%$ 
penduduk Indonesia yang belum memiliki jamban, dari 2,4 milliar penduduk dunia yang tidak memiliki jamban, dengan rasio tujuh dari sepuluh orang di dunia masih BAB di tempat terbuka, dimana sebagian besar adalah di sungai (WHO/Unicef. 2015). Di Indonesia, kloset leher angsa yang digunakan 84,4\%, plengsengan $4,8 \%$, cemplung atau cubluk tanpa lantai 7,2\%, cemplung dengan lantai $3,7 \%$. Kota Madiun yang memiliki jamban sendiri 1263, Jamban bersama 140, jamban umum 89, dan yang tidak punya jamban 617 (Riskesda, 2013).

Menurut data puskesmas Manguharjo tahun 2019 dari 855 rumah yang dilakukan pemeriksaan sebanyak 530 rumah tangga, rumah tangga yang memiliki sarana sanitasi dasar berupa jamban di wilayah kerja Puskesmas Manguharjo sebesar 420 rumah tangga atau $79 \%$ tetapi dengan sarana yang kurang memenuhi syarat kesehatan, terutama pembuangan air limbah. Hasil studi awal yang dilakukan sebelumnya pada 88 masyarakat desa Nambangan Kidul, menunjukkan 36,4\% kondisi jamban yang ada di masyarakat tidak memenuhi syarat jamban sehat (Puskesmas Manguharjo, 2018).

Berdasarkan dari penjelasan latar belakang tersebut diatas, maka peneliti tertarik untuk mengatahui lebih lanjut tentang faktor determinan apa saja yang mempengaruhi kepemilikan jamban sehat di masyarakat desa Nambangan Kidul, Manguharjo, Kota Madiun.

\section{METODE PENELITIAN}

Penelitian ini dilakukan di desa Nambangan Kidul, Manguharjo, Kota Madiun yang terdiri dari 8 dusun dengan 27 RT/ 12 RW, pada tanggal April - Mei 2019, dengan menggunakan rancangan penelitian obeservasional deskriptif analitik dengan pendekatan Cross Sectional.

Populasi dalam penelitian ini adalah seluruh ibu yang mempunyai balita di desa Nambangan Kidul, Manguharjo, Kota Madiun sebanyak 327 orang. Jumlah sampel 64 orang dilakukan proporsional (purposive sampling) setiap Dusun dan penentuan sampel menggunakan random sampling pada balita. Instrumen yang digunakan untuk mengetahui dan meneliti adalah kuesioner yang berkaitan dengan karakteristik responden dan faktor-faktor yang mempengaruhi kepemilikan jamban sehat.

\section{HASIL DAN PEMBAHASAN}

\section{Karakteristik Responden}

Tabel 1. Distribusi Frekuensi Responden Berdasarkan Umur di Desa Nambangan Kidul

\begin{tabular}{ccc}
\hline Umur & F & $\%$ \\
\hline 20-30 tahun & 14 & 21.9 \\
$31-40$ tahun & 18 & 28.1 \\
41-50 tahun & 17 & 26.6 \\
51 tahun ke atas & 11 & 17.2 \\
\hline Jumlah & 64 & 100 \\
\hline
\end{tabular}

Berdasarkan tabel 1, usia responden yang menarik untuk dipaparkan adalah usia diatas 51 tahun ke atas, sebanyak $17,2 \%$. Responden tersebut merupakan anggota keluarga, misalnya nenek, atau saudara dari orangtua yang mengasuh balita di rumah ketika ibu balita sedang bekerja. 


\section{Jurnal Delima Harapan 2021}

\section{Analisis Univariat}

Tabel 2. Distribusi Frekuensi Responden Berdasarkan Kepemilikan Jamban, Pendidikan, Pengetahuan, Sikap, Penghasilan dan Penyuluhan di Desa Nambangan Kidul

\begin{tabular}{llcc}
\hline \multicolumn{1}{c}{ Variabel } & \multicolumn{1}{c}{ Kategori } & Frekuensi & Persen $(\boldsymbol{\%})$ \\
\hline Kepemilikan Jamban & Ya & 24 & 37.5 \\
& Tidak & 40 & 62.5 \\
Pendidikan & Rendah & 48 & 75.0 \\
& Tinggi & 16 & 25.0 \\
Pengetahuan & Kurang baik & 16 & 25.0 \\
\multirow{2}{*}{ Sikap } & Baik & 48 & 75.0 \\
\multirow{3}{*}{ Penghasilan } & Kurang baik & 23 & 35.9 \\
& Baik & 41 & 64.1 \\
Penyuluhan & Rendah & 23 & 35.9 \\
& Tinggi & 41 & 64.1 \\
& Ada Penyuluhan & 9 & 14.1 \\
\hline
\end{tabular}

Berdasarkan tabel 2 usia yang menarik untuk dipaparkan adalah usia diatas 51 tahun ke atas, sebanyak $17,2 \%$. Responden tersebut merupakan anggota keluarga, misalnya nenek, atau saudara dari orangtua yang mengasuh balita di rumah ketika ibu balita sedang bekerja. Pendidikan responden $75 \%$ termasuk pendidikan rendah namun $75 \%$ responden pengetahuannya baik dan $64,1 \%$ sikap juga baik. Sedangkan penghasilan responden $64,1 \%$ termasuk kategori tinggi. Penyuluhan petugas kesehatan tergolong masih rendah hanya $14,1 \%$.

\section{Analisis Bivariat}

1. Hubungan Pendidikan dengan Kepemilikan Jamban

Tabel 3. Hubungan Pendidikan dengan Kepemilikan Jamban di Desa Nambangan Kidul

\begin{tabular}{|c|c|c|c|c|c|r|}
\hline \multirow{2}{*}{ Pendidikan } & \multicolumn{3}{|c|}{ Kepemilikan Jamban } & \multirow{2}{*}{ P value } & \multicolumn{1}{c|}{ CI 95\% } \\
\cline { 2 - 5 } & \multicolumn{2}{|c|}{ Ya } & \multicolumn{2}{c|}{ Tidak } & & \\
\cline { 2 - 5 } & $\mathrm{F}$ & $\%$ & $\mathrm{~F}$ & $\%$ & & 2.692 \\
\hline Rendah & 26 & 65 & 20 & 83.3 & 0.196 & $(0.768-9.442)$ \\
\hline Tinggi & 14 & 35 & 4 & 16.7 & & \\
\hline Jumlah & 40 & 100 & 24 & 100 & & \\
\hline
\end{tabular}

Berdasarkan tabel 3. diketahui pendidikan rendah yang memiliki jamban yaitu $65 \%$ dan pendidikan tinggi yang memiliki jamban sebesar 35\%. Hasil uji statistik Chi Square menyatakan tidak terdapat hubungan yang bermakna antara pendidikan dengan kepemilikan jamban dengan $\mathrm{p}$ value $=0.196$. Pendidikan yang rendah beresiko 2.692 kali lebih besar tidak memiliki jamban dibandingkan pendidikan tinggi. Hasil tersebut menggarisbawahi pendapat Vivi (2016) dipemukiman nelayan Kenagarian Air Bangis Kec. Sungai Beremas Kab. Pasaman Barat. Secara statistik menyatakan tidak ada hubungan yang bermakna antara pendidikan dengan kepemilikan jamban keluarga 


\section{Jurnal Delima Harapan 2021}

2. Hubungan Penghasilan dengan kepemilikan jamban

Tabel 4. Hubungan Penghasilan dengan kepemilikan jamban di Desa Nambangan Kidul

\begin{tabular}{|c|c|c|c|c|c|r|}
\hline \multirow{2}{*}{ Penghasilan } & \multicolumn{4}{|c|}{ Kepemilikan Jamban } & \multirow{2}{*}{ P value } & \multicolumn{1}{c|}{ CI 95\% } \\
\cline { 2 - 5 } & \multicolumn{2}{|c|}{ Ya } & \multicolumn{2}{c|}{ Tidak } & & \\
\cline { 2 - 5 } & $\mathrm{F}$ & $\%$ & $\mathrm{~F}$ & $\%$ & & 3.667 \\
\hline Rendah & 18 & 45 & 18 & 75 & 0.037 & \\
\hline Tinggi & 22 & 55 & 6 & 25 & & $(1.203-11.174)$ \\
\hline Jumlah & 40 & 100 & 24 & 100 & & \\
\hline
\end{tabular}

Berdasarkan tabel 4 diketahui keluarga penghasilan rendah yang memiliki jamban sebesar $45.0 \%$ dan penghasilan tinggi sebesar 55\%. Hasil uji statistik dengan menggunakan uji chi square dinyatakan bahwa terdapat hubungan bermakna antara penghasilan dengan kepemilikan jamban dengan $\mathrm{p}$ value $=0,037$. Penghasilan rendah beresiko 3.667 kali tidak memiliki jamban dibandingkan dengan penghasilan tinggi yang tidak memiliki jamban.

Status ekonomi seseorang juga akan menentukan tersedianya suatu fasilitas yang diperlukan untuk kegiatan tertentu, sehingga status sosial ekonomi ini akan mempengaruhi perubahan perilaku pada diri seseorang.
Berdasarkan hasil penelitian yang dilakukan oleh Darsana pada tahun 2014 di Desa Jehem Kec. Tembuku Kab. Bangli, secara statistik dibuktikan bahwa ada hubungan yang bermakna antara ekonomi dengan kepemilikan jamban keluarga $\rho=0,000<\alpha(0,05)$. Dengan demikian dapat disimpulkan dari hasil penelitian yang dilakukan oleh peneliti bahwa ekonomi merupakan alat ukur tingkat kesejahteraan suatu masyarakat. Karena ekonomi merupakan indikator penentu perilaku masyarakat dalam pemenuhan kebutuhan sehari-hari termasuk pemanfaatan jamban keluarga (Notoatmodjo 2007).

\section{Hubungan pengetahuan dengan kepemilikan jamban}

Tabel 5. Hubungan pengetahuan dengan kepemilikan jamban di Desa Nambangan Kidul

\begin{tabular}{|c|c|c|c|c|c|r|}
\hline \multirow{2}{*}{ Pengetahuan } & \multicolumn{4}{|c|}{ Kepemilikan jamban } & P Value & \multicolumn{1}{c|}{ PR } \\
\cline { 2 - 5 } \cline { 3 - 4 } & \multicolumn{2}{|c|}{ Ya } & \multicolumn{2}{|c|}{ Tidak } & & \multirow{2}{*}{$($ CI 95\%) } \\
\cline { 2 - 5 } & $\mathrm{N}$ & $(\%)$ & $\mathrm{N}$ & $(\%)$ & & 0.169 \\
\hline Kurang baik & 14 & 35.0 & 2 & 8.3 & 0,037 & $(0.035-0.825)$ \\
\hline Baik & 26 & 65.0 & 22 & 91.7 & & \\
\hline Jumlah & 40 & 100 & 24 & 100 & & \\
\hline
\end{tabular}

Berdasarkan tabel 5. diatas diketahui pengetahuan yang baik hanya $65 \%$ yang memiliki jamban, sebaliknya dari seluruh responden yang tidak memiliki jamban $91,7 \%$ berasal dari responden dengan pengetahuan baik. Hasil uji statistik dengan chi square menyatakan bahwa terdapat hubungan bermakna antara pengetahuan dengan kepemilikan jamban dengan pvalue $=0.037$. pengetahuan kurang baik beresiko 0.169 kali tidak memiliki jamban dibandingkan dengan pengetahuan baik yang tidak memiliki jamban.

Pengetahuan merupakan hasil "tahu" penginderaan manusia terhadap Suatu objek tertentu. Proses pengindraan terjadi melalui panca indra manusia yakni penglihatan, pendengaran, penciuman, rasa, dan melalui kulit. Pengetahuan natau kognitif merupakan domain yang sangat penting untuk terbentuknya tindakan seseorang (Ibrahim, 2012).

Berdasarkan hasil penelitian yang dilakukan Ibrahim (2012) di Desa Pintu Langit Jae Kecamatan Padang Sidimpuan Angkola Julu. Secara statistik dibuktikan bahwa ada hubungan yang bermakna antara pengetahuan dengan pemanfaatan jamban $\rho$ $=0,000<\alpha(0,05)$. (Azwar, S. 2008).

Dengan demikian dapat disimpulkan dari hasil penelitian yang dilakukan oleh peneliti bahwa Pemanfaatan Jamban Keluarga (JAGA) oleh masyarakat dengan pengetahuan yang cukup memiliki kemampuan dalam memanfaatkan jamban keluarga (JAGA) dibanding dengan 
masyarakat dengan pengetahuan yang

kurang.

4. Hubungan sikap dengan kepemilikan jamban

Tabel 6. Hubungan Sikap dengan Kepemilikan Jamban di Desa Nambangan Kidul

\begin{tabular}{|c|c|c|c|c|c|c|}
\hline \multirow{2}{*}{ Sikap } & \multicolumn{4}{|c|}{ Kepemilikan jamban } & P Value & \multicolumn{1}{c|}{ PR } \\
\cline { 2 - 5 } \cline { 3 - 4 } & \multicolumn{2}{|c|}{ Ya } & \multicolumn{2}{|c|}{ Tidak } & & \multirow{2}{*}{$($ CI 95\%) } \\
\cline { 2 - 5 } & $\mathrm{N}$ & $(\%)$ & $\mathrm{N}$ & $(\%)$ & & 3.545 \\
\hline Kurang baik & 10 & 25 & 13 & 54.2 & 0,037 & $(1.209-10.394)$ \\
\hline Baik & 30 & 75 & 11 & 45.8 & & \\
\hline Jumlah & 40 & 100 & 24 & 100 & & \\
\hline
\end{tabular}

Berdasarkan tabel 6. Sikap responden yang kurang baik dan memiliki jamban sebesar $25 \%$ dan sikap baik yang memiliki jamban sebesar $75 \%$. Hasil uji Chi Square menyatakan bahwa terdapat hubungan yang bermakna antara sikap yang kurang baik dengan kepemilikan jamban pada balita dengan $p$ value $=0.037$. Sikap kurang baik beresiko 3.545 kali tidak memiliki jamban dibandingkan sikap baik yang tidak memiliki jamban. Sikap merupakan kesiapan untuk bereaksi terhadap suatu objek dengan cara-cara tertentu kesipan yang dimaksud disini adalah kecendrungan potensial untuk bereaksi dengan cara tertentu apabila individu dihadapkan pada stimulus yang menghendaki adanya respon (Azwar, 2008).
Berdasarkan hasil penelitian yang dilakukan Ibrahim (2012) Desa Pintu Langit Jae Kecamatan Padang Sidimpuan Angkola Julu. Secara statistik dibuktikan bahwa ada hubungan yang bermakna antara sikap dengan pemanfaatan jamban $\rho=0,000<\alpha$ $(0,05)$.

Dengan demikian dapat disimpulkan dari hasil penelitian yang dilakukan oleh peneliti bahwa sikap positif masyarakat terhadap masalah kesehatan sangat besar pengaruhnya terhadap perilaku masyarakat dalam Pemanfaatan Jamban Keluarga (JAGA)

\section{Hubungan peran petugas kesehatan dengan kepemilikan jamban}

Tabel 7. Hubungan peran petugas kesehatan dengan kepemilikan jamban Desa Nambangan Kidul

\begin{tabular}{|c|c|c|c|c|c|c|}
\hline \multirow{2}{*}{$\begin{array}{c}\text { Peran Petugas } \\
\text { Kesehatan }\end{array}$} & \multicolumn{3}{|c|}{ Kepemilikan jamban } & P Value & \multicolumn{1}{c|}{ PR } \\
\cline { 2 - 5 } & $\mathrm{Na}$ & $(\%)$ & $\mathrm{N}$ & $(\%)$ & & \multirow{2}{*}{ (CI 95\%) } \\
\cline { 2 - 5 } $\begin{array}{c}\text { Tidak Mendapat } \\
\text { Penyuluhan }\end{array}$ & 34 & 85 & 21 & 87.5 & 1.000 & 1.235 \\
\hline $\begin{array}{c}\text { Mendapat } \\
\text { Penyuluhan }\end{array}$ & 6 & 15 & 3 & 12.5 & & $(0.279-5.475)$ \\
\hline Jumlah & 40 & 100 & 24 & 100 & & \\
\hline
\end{tabular}

Berdasarkan tabel 7. Diatas, responden yang tidak mendapat penyuluhan dan memiliki jamban sebesar $85 \%$ dan mendapat penyuluhanyang memiliki jamban sebesar $15 \%$. Hasil uji Chi Square menyatakan bahwa tidak terdapat hubungan yang bermakna antara tidak mendapatkan penyuluhan dengan kepemilikan jamban pada balita dengan $p$ value $=1.000$. Tidak mendapat penyuluhan beresiko $1.235 \mathrm{kali}$ tidak memiliki jamban dibandingakn dengan yang mendapat penyuluhan.
Petugas kesehatan merupakan setiap oaring yang mengabdikan diri dalam bidang kesehatan serta memiliki pengetahuan dan/keterampilan melalui pendidikan di bidang kesehatan yang untuk jenis tertentu memerlukan kewenangan untuk melakukan upaya kesehatan.

Salah satu unsur yang berperan dalam percepatan pembangunan kesehatan adalah tenaga kesehatan yang bertugas di sarana pelayanan kesehatan di masyarakat. Hal ini tidak sejalan dengan hasil penelitian yang 


\section{Jurnal Delima Harapan 2021}

dilakukan oleh Darsana (2014) di Desa Jehem Kec. Tembuku Kab. Bangli. Secara statistic dibuktikan bahwa ada hubungan yang bermakna antara peranan petugas kesehatan dengan kepemilikan jamban keluarga $p$ value $=0.01, \alpha(0.05)$.

Berdasarkan hasil analisa statistik, maka dapat disimpulkan faktor determinan yang berpengaruh terhadap kepemilikan jamban di Desa Nambangan Kidul adalah sebagai berikut:

1. Hasil survei penentuan faktor determinan menyatakan tidak terdapat hubungan antara pendidikan dengan kepemilikan jamban pada balita $(\mathrm{p}$ value $=0,196)$. Dan berdasarkan hasil uji chi-square PR = 2.692 .

2. Hasil survei penentuan faktor determinan menyatakan terdapat hubungan antara penghasilan dengan kepemilikan jamban pada balita ( $\mathrm{p}$ value $=0,037)$. Dan berdasarkan hasil chi-square $\mathrm{PR}=3.667$

3. Hasil survei penentuan faktor determinan menyatakan terdapat hubungan antara pengetahuan dengan kepemilikan jamban pada balita ( $\mathrm{p}$ value $=0,037)$. Dan berdasarkan hasil chi-square $\mathrm{PR}=0.169$

4. Hasil survei penentuan faktor determinan menyatakan terdapat hubungan antara sikap dengan kepemilikan jamban pada balita ( $p$ value $=0,037$ ). Dan berdasarkan hasil chisquare $\mathrm{PR}=3.545$

5. Hasil survei penentuan faktor determinan menyatakan tidak terdapat hubungan antara peran petugas kesehatan dengan kepemilikan jamban pada balita $(\mathrm{p}$ value $=$ 1.000). Dan berdasarkan hasil chi-square $\mathrm{PR}=1.235$

Kepemilikan jamban di desa Nambangan Kidul, Manguharjo, Kota Madiun masih membutuhkan banyak perhatian dari pemerintah. Sebagian besar masyarakat yang ada mempunyai jamban, ternyata masih banyak yang tidak memenuhi syarat jamban sehat yaitu dengan menggali tanah sebagai jamban, dan sisanya tidak mempunyai jamban atau BAB di sungai.

\section{KESIMPULAN}

1. Ada hubungan antara pendidikan, penghasilan, pengetahuan, dan sikap dengan kepemilikan jamban,

2. Tidak terdapat hubungan antara peran petugas kesehatan dengan kepemilikan jamban.
DAFTAR PUSTAKA

1. Putranti, Dya CMS, dkk. 2013. Hubungan Antara Kepemilikan Jamban dengan Kejadian Diare di Desa Karangagung Kecamatan Palang Kabupaten Tuban. Diakses 7 April 2019 pada URL : http://www.journal.unair.ac.id/filer PDF/keslingb03cb54364full.pdf

2. Erlina. 2015. Faktor yang Berhubungan dengan PHBS pada Tatanan Rumah Tangga Menggunakan Jamban Sehat. Jurnal Ilmiah Keperawatan STIKesMedika. Cikarang. vol.5, No.1.

3. WSP-EAP. 2008. Economic Impacts of Sanitation in Indonesia. Research Report. $21-30$.

4. Wijaya, Yulianto. Faktor Risiko Kejadian Diare Balita Di Sekitar Tps Banaran Kampus Unnes. Unnes Journal of Public Health. Diakses pada tanggal 20 April 2019 pada URL

http://journal.unnes.ac.id/sju/index php/ujph/article/view/3050

5. Darsana, I Nengah. 2014. Faktor Yang Berhubungan Dengan Kepemilikan Jamban Keluarga. Jurnal Kesehatan Lingkungan. Diakses pada tanggal 20 April 2019 pada URL : http://poltekkesdenpasar.ac.id/files/JURNAL\%20KES EHATAN\%2OLINGKUNGAN/V4N2/I \%20Nengah\%20Darsanal,\%20I\%20 Made\%20Bulda\%20Mahayana2,\%20 I\%20Made\%20Patra3.pdf

6. Zainiyah, Alif N, dkk. 2013. Hubungan kepemilikan Jamban dengan Tingkat Pengetahuan dan Pendidikan Masyarakat (Studi di Desa Mendalan Kecamatan Winongan Kabupaten Pasuruan Tahun 2013) (online), diambil dari http://digilib.poltekkesdepkessby.ac.id/public/POLTEKKESSBYPublication-529-

AlifNurilSriMardoyo.pdf , diakses pada tanggal 6 April 2019.

7. WHO/Unicef. 2015. 25 Years Progress on Sanitation and Drinking Water. http://www.depkes.go.id/resources /download/general/Hasil\%20Riske 


\section{Jurnal Delima Harapan 2021}

sdas\%202013.pdf . (online). diakses pada tanggal 6 April 2019.

8. Riskesda, 2013. http://www.depkes.go.id/resources /download/general/Hasil\%20Riske sdas\%202013.pdf . (online). diakses pada tanggal 6 April 2019.

9. Mempawah Hilir. 2014. Laporan Bulanan Puskesmas Mempawah Hilir

10. Vivi maya sari .2016. Faktor Yang Berhubungan Dengan Pemanfaatan Jamban Community Letd Total Sanitation (CLTS) Di Kenagarian Kurnia Selatan Kecamatan Sungai Rumbai Kabupaten Dharmasraya. Diakses pada tanggal 8 April 2019 pada URL

http://repository.unand.ac.id/2004 0/1/Jurnal\%20ku.pdf
11. Notoatmodjo. 2007. Kesehatan Masyarakat Ilmu dan Seni. Rineka Cipta, Jakarta.

12. Ibrahim, Ikhsan, dkk. 2012. FaktorFaktor Yang Berhubungan Dngan Pemanfaatan Jamban Di Desa Pintu Langit Jae Kecamatan Padangsimpuan Angkola Julu. Diakses pada tanggal 22 April 2019 pada URL : http://download.portalgaruda.org/a rticle.php?article $=110065 \&$ val $=411$ 0 \&title $=$ FAKTOR-

FAKTOR\%20YANG\%20BERHUBUN GAN\%20DENGAN\%20PEMANFAA TAN\%20\%20JAMBAN\%20DI\%20DE SA\%20PINTU\%20LANGIT\%20JAE\% 20KECAMATAN\%20\%20PADANGS IDIMPUAN\%20ANGKOLA\%20JULU \%20\%20\%20TAHUN\%202012.

13. Azwar, S. 2008. Sikap Manusia Teori dan Pengukurannya. Yogyakarta: Liberty. 